Annals of International Medical and Dental Research

E-ISSN: 2395-2822 | P-ISSN: 2395-2814

Vol-8, Issue-1 | January-February 2022

DOI: 10.53339/aimdr.2022.8.1.14

Page no- 98-105 | Section- Research Article (Surgical Gastroenterology)

\title{
Objective Assessment of Superiority of Enteral Feeding by Traditional Home Kitchen-Based Feed V/S Commercial Formula Feed in Patients of Esophagogastric Corrosive Injury
}

\author{
Maulik S. Bhadania1, Hasmukh B. Vora ${ }^{2 *}$, Nikhil Jillawar ${ }^{3}$, Premal R. Desai $^{4}$
}

\begin{abstract}
13rd year MCh Resident Doctor, Department of Surgical Gastroenterology, Smt. NHL Municipal Medical College, SVP hospital, Ahmedabad, Gujarat, India.

Email: dr.maulik88@gmail.com

Orcid ID: 0000-0001-9664-393X

${ }^{2}$ Associate Professor, Department of Surgical Gastroenterology, Smt. NHL Municipal Medical College, SVP hospital, Ahmedabad, Gujarat, India. Email: hbvora@yahoo.com, Orcid ID: 0000-0002-6640-031X

${ }^{3}$ Assistant Professor, Department of Surgical Gastroenterology, Dr DY Patil medical college, hospital and research centre, Pimpri, Pune, Maharashtra, India.

Email: nikhiljillawar@gmail.com

Orcid ID: 0000-0003-1056-147X

4Professor and Head, Department of Surgical Gastroenterology, Smt. NHL Municipal Medical College, SVP hospital, Ahmedabad, Gujarat, India.

Email: gisvpjournal@gmail.com

Orcid ID: 0000-0001-8924-1940
\end{abstract}

*Corresponding author

Received: 24 June 2021

Revised: 07 August 2021

Accepted: 16 August 2021

Published: 22 December 2021

\begin{abstract}
Background: Corrosive ingestion can cause severe chemical injury to upper gastrointestinal tract which leads to dysphagia, malnutrition and weight loss. Early nutritional assessment and support through feeding jejunostomy is important and it should be nutritionally optimum and economically balanced. The aim is to compare cost and nutritional status after nutritional support with traditional home kitchen made and commercial formula feed through feeding jejunostomy. Methods: A prospective study included patients on enteral nutrition based on traditional home kitchen feed (cohort-1) and on commercial formula feed (cohort-2). Patient's body weight, BMI, haemoglobin, serum albumin, nutritional risk index, controlling nutritional status score were checked at the admission, 3rd and 6th month follow up. Results: In cohort 1 mean albumin and haemoglobin raised by $33.13 \%$ \& $14.60 \%$ at 3rd month and $47.23 \%$ \& $22.3 \%$ at 6th month respectively; In cohort 2 it was $9.12 \%$ \& $2.69 \%$ at 3rd month and $17.62 \% \& 6.53 \%$ at 6 th month respectively. At 6th month in cohort 1 and 2 mean weight gain was $7.56 \%$ \& $4.0 \%$; mean increase in NRI was $34.78 \%$ \& $11.5 \%$ respectively. Mean CONUT score at six months was better improved in cohort 1 which is 6 to 1 as compared to cohort 2 which was 6 to 3. Mean monthly cost of home-based feeds was significantly lower as compared to commercial feeds (62.14 Rs v/s 682-2354 Rs/day). Conclusions: In corrosive GI tract injury patient enteral nutrition with traditional home kitchen-based feeds is safe, cost effective and associated with better improvement in nutritional status objective parameters.
\end{abstract}

Keywords:- Corrosive injury, Enteral nutrition, Feeding jejunostomy, Traditional home kitchen-based feed, Commercial formula feed.

\section{INTRODUCTION}

Corrosive substance ingestion can cause severe chemical injury to the upper gastrointestinal tract from oral cavity to proximal duodenum. In the pediatric population corrosive substance ingestion is most often accidental in nature but in adults it may be intentional in more than $90 \%$ of the cases ${ }^{1}$. Acids cause coagulation necrosis and alkali causes penetrating liquefaction necrosis which causes reversible or irreversible gastrointestinal damage.[1] This type of poisoning result in serious acute complications like esophageal/gastric necrosis 
Annals of International Medical and Dental Research

E-ISSN: 2395-2822 | P-ISSN: 2395-2814

Vol-8, Issue-1 | January-February 2022

DOI: $10.53339 /$ aimdr.2022.8.1.14

Page no- 98-105 | Section- Research Article (Surgical Gastroenterology)

and perforation, metabolic acidosis, acute kidney injury, tracheal necrosis, acute respiratory distress syndrome, laryngeal edema and subsequently tracheoesophageal fistula, esophageal stricture or pyloric stenosis etc which causes significant morbidity, mortality and socioeconomic burden to family and society. [1]

The severity of the injury depends on several factors like nature, quantity and concentration of the corrosive substance, duration of exposure, act of swallowing, presence of food in stomach, various previous pathologic conditions of the upper gastrointestinal tract and other existing morbid condition of the patient.[2]

If a patient survives the acute phase of injury, regeneration and fibrosis may result in stenosis of esophagus and/or stomach. It greatly impairs the upper gastrointestinal tract function resulting in dysphagia with or without gastric outlet obstruction. These patients are in hypercatabolic state and in negative nitrogen balance which leads to malnutrition, deficiency of micro and macronutrients, weight loss and cachexia. Nutritional status assessment and early nutritional support is very important for stimulation of healing of injury, reduction of infection risk, treatment related morbidity and mortality.[3] Many of these patients belong to low socioeconomic class so any long-term nutritional support through feeding jejunostomy has to be nutritional optimum and economically balanced.[4] In this study we objectively compare cost and nutritional status parameters after nutritional support with traditional home kitchen made formula feed and commercial formula feed. The traditional home kitchen made formula feed prepared according to vegetarian food habit of most of population of Gujarat.

\section{MATERIAL AND METHODS}

A prospective cohort study (50 subjects each) was conducted in the Department of Surgical Gastroenterology, Smt NHL municipal medical college, Ahmedabad including patients of corrosive injury on enteral nutrition by feeding jejunostomy who are on OPD follow up during the study period. Cohort-1 included patients on feeding jejunostomy enteral nutrition based on exclusively traditional home kitchen-based feed while cohort-2 included patients on feeding jejunostomy enteral nutrition based on commercial formula feed.

Traditional home kitchen-based feed [Table 1] consists of commonly used vegetarian food items based on local vegetarian food culture and social tradition in Gujarat that are blenderized and given as tube feeding. This was made at a patient's home by using commonly available vegetarian food items like milk, paneer, curd, wheat, rice, dhal, vegetable, fruits, edible oil, ghee, jaggery etc. and calculated according to patient requirement. A sample of food stuffs that we are used for a recipe for a homemade formula for one day is demonstrated in [Table 1]. This composition contains $2207 \quad$ kilocalorie, $249.02 \mathrm{~g}$ carbohydrate, $96.75 \mathrm{~g}$ protein and $106.25 \mathrm{~g}$ fat. Commercial formula feeds [Table 2] include commercially available polymeric feeds and pre-digested feeds that are routinely taken and used by our patients. Multivitamins and multimineral were supplemented in both the groups of patients. 
Annals of International Medical and Dental Research E-ISSN: 2395-2822 | P-ISSN: 2395-2814

Vol-8, Issue-1 | January-February 2022

DOI: $10.53339 /$ aimdr.2022.8.1.14

Page no- 98-105 | Section- Research Article (Surgical Gastroenterology)

Table 1: A sample of food stuffs used for a recipe for traditional home kitchen-based feed. ${ }^{\text {[4] }}$

\begin{tabular}{|c|c|c|c|c|c|c|}
\hline & Amount & Calories (kcal) & Carbohydrate (g) & Fat $(g)$ & Protein (g) & Cost (Rs) \\
\hline \multicolumn{7}{|c|}{ Solid food (400g) } \\
\hline Wheat flour & $120 \mathrm{~g}$ & 406 & 87 & 1.2 & 16.4 & 3 \\
\hline Rice & $30 \mathrm{~g}$ & 104 & 23 & 0.15 & 1.95 & 1.2 \\
\hline Gram flour & $120 \mathrm{~g}$ & 464 & 70 & 8.4 & 26.4 & 10.8 \\
\hline Soyabean & $60 \mathrm{~g}$ & 268 & 18 & 12 & 21.6 & 6 \\
\hline Jaggery & $20 \mathrm{~g}$ & 76.6 & 19.62 & Nil & Nil & 1.8 \\
\hline Peanut & $50 \mathrm{~g}$ & 283.5 & 8 & 24.5 & 13 & 5 \\
\hline \multicolumn{7}{|c|}{ Liquid food $(630 \mathrm{ml})$} \\
\hline Ghee & $20 \mathrm{ml}$ & 180 & 00 & 30 & 00 & 9 \\
\hline $\begin{array}{l}\text { Groundnut } \\
\text { oil }\end{array}$ & $10 \mathrm{ml}$ & 88.4 & 00 & 10 & 00 & 1.34 \\
\hline Milk & $400 \mathrm{ml}$ & 285.2 & 18.8 & 18 & 13.2 & 20 \\
\hline Buttermilk & $200 \mathrm{ml}$ & 52 & 4.6 & 2 & 4.2 & 4 \\
\hline \multicolumn{2}{|l|}{ Total } & 2207 & 249.02 & 106.25 & 96.75 & 62.14 \\
\hline
\end{tabular}

\begin{tabular}{|l|l|l|l|l|l|l|l|l|}
\hline Trade Names & $\begin{array}{l}\text { Energy } \\
(\mathbf{k c a l})\end{array}$ & $\begin{array}{l}\text { Protein } \\
(\mathbf{g})\end{array}$ & $\begin{array}{l}\text { Carbohydrate } \\
(\mathbf{g})\end{array}$ & $\begin{array}{l}\text { Fat } \\
(\mathbf{g})\end{array}$ & Cost (Rs) & $\begin{array}{l}\text { Cost } \\
(\mathbf{R s}) / \text { serving }\end{array}$ & $\begin{array}{l}\text { Cost } \\
(\mathbf{R s}) / \mathbf{k c a l}\end{array}$ & $\begin{array}{l}\text { Cost } \\
(\mathbf{R s}) / g \text { of } \\
\text { protein }\end{array}$ \\
\hline Nutrilite 30 g & 120 & 15 & 0.9 & 1.5 & $\begin{array}{l}4000 / 1 \\
\mathrm{~kg}\end{array}$ & 120 & 1 & 8 \\
\hline $\begin{array}{l}\text { Lamino gi } \\
\text { plus 30 g }\end{array}$ & 112 & 18 & 6 & 1.8 & $800 / 200 \mathrm{~g}$ & 120 & 1.07 & 6.67 \\
\hline $\begin{array}{l}\text { Essential HP } \\
\text { 25 g }\end{array}$ & 92.25 & 10.75 & 11.12 & 0.67 & $800 / 400 \mathrm{~g}$ & 50 & 0.54 & 4.65 \\
\hline Fresubin 50 g & 220 & 8.25 & 29.5 & 7.35 & $545 / 400 \mathrm{~g}$ & 68 & 0.31 & 8.24 \\
\hline
\end{tabular}

All patients have a feeding jejunostomy tube placed Weitzel technique using 12 Fr Ryle's tube. Feeding is administered as an infusion over 30 minutes using a feeding bag every 2 hours. Patients generally receive 8-9 feeds per day according to the patient's tolerability. Total calories of 30-35 kcal $/ \mathrm{kg}$ and protein of 1.5-2.0 $\mathrm{g} / \mathrm{kg}$ were given. At regular OPD visits each patient or family member was trained in tube feeding, diet administration, wound care, equipment handling and monitoring for complications. All patients were monitored by telephonic contact at regular intervals. Patient's physical examination, measurement of body weight, BMI, hemoglobin, serum albumin, Nutritional Risk Index (NRI), []] controlling 
Annals of International Medical and Dental Research

E-ISSN: 2395-2822 | P-ISSN: 2395-2814

Vol-8, Issue-1 | January-February 2022

DOI: 10.53339/aimdr.2022.8.1.14

Page no- 98-105 | Section- Research Article (Surgical Gastroenterology)

nutritional status (CONUT) score were checked at the beginning, at one, three and six months follow up period.[6]

The NRI calculated by following formula:[ $[$ ]

$\mathrm{NRI}=[1.519 \times \mathrm{x}$. Albumin $(\mathrm{g} / \mathrm{l})]+[41.7 \times$

\{Present Weight(kg)/Usual Weight(kg)\}].
(NRI >100 no risk of malnutrition, 97.5 - 100 mild risk of malnutrition, 83.5 - 97.5 moderate risk of malnutrition, $<83.5$ severe risk of malnutrition.)

Table 2: The CONUT score. ${ }^{[6]}$

\begin{tabular}{|l|l|l|l|l|l|}
\hline S. Albumin(g/dl) & Points & Total Cholesterol(mg/dl) & Points & Lymphocyte Count $\left(\mathbf{m m}^{\mathbf{3}}\right)$ & Points \\
\hline 2.5 & 6 & $<800$ & 3 & $<100$ & 3 \\
\hline $2.5-<3$ & 4 & $800-<1200$ & 2 & $100-<140$ & 2 \\
\hline $3-<3.5$ & 2 & $1200-<1600$ & 1 & $140-<180$ & 1 \\
\hline$>3.6$ & 0 & 0 & $>180$ & 0 \\
\hline $0-2$ normal, 3-4 mild malnutrition, 5-8 moderate malnutrition, 9-12 marked malnutrition \\
\hline
\end{tabular}

Statistical analysis was done using SPSS ver. 20 software. Comparisons were made by Student t-test for quantitative data and chi square test for qualitative data.

\section{RESULTS}

The mean age of the cohort- 1 was 37.6 years while that of cohort-2 was 31.8 years. Study included 31 males and 69 females. On 1st, 3rd and 6th months follow up visits mean increase in weight, BMI, serum albumin, hemoglobin was higher in patients on traditional home kitchen-based food as compared with patients on commercial formula feed. The NRI and CONUT score at follow up visits shows better nutritional status in patients on traditional home kitchen-based food as compared with patients on commercial formula feed [Table 3\&4]. Mean daily cost of traditional home kitchen-based food was significantly lower as compared to commercial formula feed.) [Table $1 \& 2]$.

Table 3: Nutritional parameters.

\begin{tabular}{|c|c|c|c|c|c|c|c|}
\hline & Cohorts & $\begin{array}{l}\text { Mean } \\
\text { hemoglobin } \\
(\mathrm{g} / \mathrm{dl})\end{array}$ & $\begin{array}{l}\text { Mean S. } \\
\text { Albumin } \\
\text { (g/dl) }\end{array}$ & $\begin{array}{l}\text { Mean } \\
\text { BMI }\end{array}$ & $\begin{array}{l}\text { Mean } \\
\text { weight } \\
\text { (kg) } \\
\end{array}$ & $\begin{array}{l}\text { Mean } \\
\text { NRI }\end{array}$ & $\begin{array}{l}\text { Mean } \\
\text { CONUT } \\
\text { score }\end{array}$ \\
\hline \multirow[t]{2}{*}{ Admission } & Cohort-1 & 11.3 & 3.26 & 20.97 & 64.32 & 87.18 & 6 \\
\hline & Cohort-2 & 12.25 & 3.29 & 21.13 & 61.65 & 89.65 & 6 \\
\hline \multirow{2}{*}{$\begin{array}{l}1^{\text {st }} \text { Month } \\
\text { follow up }\end{array}$} & Cohort-1 & 11.71 & 3.84 & 21.22 & 65.12 & 97.31 & 4 \\
\hline & Cohort-2 & 12.18 & 3.27 & 21.24 & 61.96 & 89.52 & 6 \\
\hline \multirow{2}{*}{$\begin{array}{l}\text { 3rd Month } \\
\text { follow up }\end{array}$} & Cohort-1 & 12.95 & 4.34 & 21.74 & 66.69 & 105.9 & 2 \\
\hline & Cohort-2 & 12.58 & 3.59 & 21.54 & 62.84 & 94.85 & 3 \\
\hline \multirow{2}{*}{$\begin{array}{l}6^{\text {th }} \text { Month } \\
\text { follow up }\end{array}$} & Cohort-1 & 13.82 & 4.8 & 22.55 & 69.18 & 117.5 & 1 \\
\hline & Cohort-2 & 13.05 & 3.87 & 21.98 & 64.12 & 99.96 & 3 \\
\hline
\end{tabular}


Annals of International Medical and Dental Research

E-ISSN: 2395-2822 | P-ISSN: 2395-2814

Vol-8, Issue-1 | January-February 2022

DOI: 10.53339/aimdr.2022.8.1.14

Page no- 98-105 | Section- Research Article (Surgical Gastroenterology)

Table 4: Change in nutritional parameters (\%).

\begin{tabular}{|c|c|c|c|c|c|c|}
\hline & Cohorts & $\begin{array}{l}\text { Mean } \\
\text { hemoglobin (\%) }\end{array}$ & $\begin{array}{l}\text { Mean S. } \\
\text { Albumin (\%) }\end{array}$ & $\begin{array}{l}\text { Mean } \\
\text { BMI }(\%)\end{array}$ & $\begin{array}{l}\text { Mean } \\
\text { weight }(\%)\end{array}$ & $\begin{array}{l}\text { Mean NRI } \\
(\%)\end{array}$ \\
\hline \multirow{2}{*}{$\begin{array}{l}1^{\text {st }} \text { Month } \\
\text { follow up }\end{array}$} & Cohort-1 & 3.62 & 17.79 & 1.19 & 1.24 & 11.62 \\
\hline & Cohort-2 & -0.57 & -0.61 & 0.52 & 0.5 & -0.15 \\
\hline \multirow{2}{*}{$\begin{array}{l}\text { 3rd Month } \\
\text { follow up }\end{array}$} & Cohort-1 & 14.6 & 33.13 & 3.67 & 3.68 & 21.47 \\
\hline & Cohort-2 & 2.69 & 9.12 & 1.94 & 1.93 & 5.8 \\
\hline \multirow{2}{*}{$\begin{array}{l}6^{\text {th }} \text { Month } \\
\text { follow up }\end{array}$} & Cohort-1 & 22.3 & 47.23 & 7.53 & 7.56 & 34.78 \\
\hline & Cohort-2 & 6.53 & 17.62 & 4.02 & 4 & 11.5 \\
\hline
\end{tabular}

\section{DISCUSSION}

After acute corrosive intoxication it is very important to maintain hemodynamic stability of the patient. A complete clinical and radiological assessment done to rule out any esophageal and/or gastric perforation. Endoscopic assessment done at 24 to 48 hours of ingestion to grade the corrosive injury and to prognosticate the patient. In our institute feeding jejunostomy done if the patient cannot swallow liquid at 5 to 7 days after corrosive ingestion for nutritional support. It is considered that nutritional support plays a major role in maintenance of metabolic processes and prevention of severe metabolic and infectious complications that could additionally aggravate the condition. [7] Currently, there is a strong evidence confirming that malnutrition is an independent risk factor for higher morbidity, lower quality of life, longer hospital stays, delayed recovery time, higher hospital costs and higher mortality. [8] In critically ill patient 4-fold increase in complications and 6-fold increase in mortality if the albumin level is below 35 g/L.[9]

Current practice recommendations for EN formulated by the American Society for
Parenteral and Enteral Nutrition state that selection of the enteral formulation must rely on several variables such as nutritional and physical assessment, nutritional needs of the patient, the amounts of macro and micronutrients available in the formula, metabolic abnormalities, gastrointestinal function, overall medical condition (renal, hepatic, cardiac and/or respiratory dysfunction), food sensitivities and/or lactose intolerance in the patient and expected outcomes.

Objective assessment of patients nutritional status can be done with body weight, BMI, Skinfold measurement, biochemical impedance analysis, Creatinine height index, Dual energy $x$ ray absorptiometry, magnetic resonance tomography and computed tomography (to allow the quantification of fat mass and fat-free mass, giving information about the fat distribution and enabling an estimation of skeletal muscle mass), Biochemical analysis like serum albumin, serum ferritin, prealbumin/transthyretin (TTR), retinol binding protein, insulin like growth factor 1, urinary creatinine, lymphocyte count, nutritional risk index (NRI) and controlling nutritional status (CONUT) score etc. 
Annals of International Medical and Dental Research

E-ISSN: 2395-2822 | P-ISSN: 2395-2814

Vol-8, Issue-1 | January-February 2022

DOI: 10.53339/aimdr.2022.8.1.14

Page no- 98-105 | Section- Research Article (Surgical Gastroenterology)

The Nutritional Risk Index (NRI) ${ }^{5}$ objectively assess the nutritional status of the patients or effect of nutritional intervention. The NRI is based on serum albumin concentration and percentage of usual weight.

The Controlling Nutritional Status (CONUT) score [Table 2] is a screening tool to identify undernourished patients.[6] The score is derived from the values of serum albumin, total cholesterol and lymphocyte counts. Albumin represents the protein reserves; total cholesterol represents caloric depletion; and lymphocyte count represents immune defence. The decrease in each component was assigned with a higher score which means poorer nutritional status.

To our best knowledge, there are no studies in India who compared exclusive home kitchen feeds with commercial feeds in maintaining nutrition through feeding jejunostomy in patients of corrosive ingestion. In present study, we thus attempted to fill this void in literature.

In present study, increase in mean albumin and hemoglobin level in patients with traditional home kitchen-based feed (cohort 1) was $33.13 \%$ and $14.60 \%$ respectively as compared with $9.12 \%$ and $2.69 \%$ respectively in patients with commercial formula feeds (cohort 2) at 3 months follow up. Increase in mean albumin and hemoglobin level in patients with traditional home kitchen-based feed (cohort 1) was $47.23 \%$ and $22.3 \%$ respectively as compared with $17.62 \%$ and $6.53 \%$ respectively in patients with commercial formula feeds (cohort 2) at 6 months follow up. we demonstrated that mean hemoglobin and albumin levels of patients on traditional home kitchen-based feed was significantly higher as compared to commercial formula feeds through feeding jejunostomy.[10]

Kick et al,[11] reported that implementation of home enteral nutrition improved clinical outcomes and decreased health care costs through weight gain in patients, reduced incidence of infectious complications and the cost of hospitalization.

Also, mean increase in weight was significantly more in traditional home kitchen-based feed as compared to commercial formula feeds at each follow up (at $1^{\text {st }}$ month $1.24 \%$ and $0.5 \%$ respectively, at $3^{\text {rd }}$ months $3.68 \%$ and $1.63 \%$ respectively and at $6^{\text {th }}$ months $7.56 \%$ and $4.0 \%$ respectively). Statistically significant weight gain ( $p$ - 0.0002) occurs in patients on traditional home kitchen-based feed at six months follow up. A study by Wang Y et al,[12] showed a shorter hospital stay in home-made formula group with a significantly lower cost and increased quality of life without significant difference in duration of enteral feeding and the incidence of complications between patients with intestinal fistula on home-made formula versus hospital (commercial) formula.

At six months follow up increase in mean Nutritional Risk Index was higher in traditional home kitchen-based feed which is $34.78 \%$ as compared to commercial formula feeds which is $11.5 \%$. Mean CONUT score at six months was better improved in case which is 6 to 1 as compared to control which was 6 to 3.

Mean monthly cost of home-based feeds was significantly lower as compared to commercial feeds (62.14 Rs v/s 682-2354 Rs for one day 
Annals of International Medical and Dental Research

E-ISSN: 2395-2822 | P-ISSN: 2395-2814

Vol-8, Issue-1 | January-February 2022

DOI: 10.53339/aimdr.2022.8.1.14

Page no- 98-105 | Section- Research Article (Surgical Gastroenterology)

energy requirement). A study by Stanislaw Klek et al ${ }^{11}$ showed that home enteral nutrition reduces complications, length of stay and health care costs.

Overall, the financial difference between home and commercial feeds and the fact that current nutritional services may not be covered by insurance so patients and their care-givers may prefer using a home-made formula. However, the amount of nutrient intakes from homemade formulas should always be taken into consideration as the amount of some micronutrients may be higher and that of some others be lower than the recommended values. Considering an effective process to standardize home-made formulas and to ensure their nutritional adequacy is essential. The issues of safety and ease of preparation of commercial formulas should not be ignored. Additionally, in cases of a need for using such special formulas as elemental formulas, it is very hard, if not impossible, to make it at home. Overall,

\section{REFERENCES}

1. Chibishev A, Pereska Z, Chibisheva V, Simonovska N. Corrosive poisonings in adults. Mater Sociomed. 2012;24(2):125-30. doi: $10.5455 / \mathrm{msm} .2012 .24 .125-$ 130.

2. Kalayarasan R, Ananthakrishnan N, Kate V. Corrosive Ingestion. Indian J Crit Care Med. 2019;23(Suppl 4): S282-S286. doi: 10.5005/jpjournals-10071-23305.

3. Zabalegui A, Miján de la Torre A, Sáez-Royuela F, López Morante A, Yuguero del Moral L, et al. Lesiones gastroesofágicas graves por cáusticos: papel del soporte nutricional [Severe gastroesophageal lesions due to caustics: the role of nutritional support]. Nutr Hosp. 1995;10(6):364-7.

4. Blumenstein I, Shastri YM, Stein J. Gastroenteric tube feeding: techniques, problems and solutions. the attempts of scientific bodies of clinical nutrition should be towards both improvement of the quality and reduction of the costs of commercial formulas and provision guidelines for making efficient home-made formulas based on different cultural food habits of various region of the country.

\section{CONCLUSIONS}

According to the present study, there is a clear advantage of traditional home kitchen-based feeds over commercial formula feeds for enteral nutrition through feeding jejunostomy in patients with corrosive injury with regards to improvement in objective parameters of nutritional status of the patients. Home-made formulas also offer economic advantage over commercial formula feeds which places less financial burden to family and society. So traditional home kitchen based enteral nutrition through feeding jejunostomy is safe, rational and effective for patients with upper gastrointestinal tract corrosive injury.

World J Gastroenterol. 2014;20(26):8505-8524. doi:10.3748/wjg.v20.i26.8505

5. Daradkeh G, Essa MM, Al-Mashaani A, Al-Adawi $S$, Arabawi S, et al. Malnutrition Indicators Which is More Predictive? Nutrition Risk Index (NRI) or Malnutrition Universal Screening Tool (MUST). J Clin Nutr Metab. 2019;2(1):2.

6. Suzuki S, Kanaji S, Yamamoto M, Oshikiri T, Nakamura T, Kakeji Y. Controlling Nutritional Status (CONUT) Score Predicts Outcomes of Curative Resection for Gastric Cancer in the Elderly. World J Surg. 2019;43(4):1076-1084. doi: 10.1007/s00268-018-04889-6.

7. Ramasamy K, Gumaste VV. Corrosive ingestion in adults. J Clin Gastroenterol. 2003;37(2):119-24. doi: 10.1097/00004836-200308000-00005.

8. Lochs H, Allison SP, Meier R, Pirlich M, Kondrup J, Schneider $\mathrm{S}$, et al. Introductory to the ESPEN 
Annals of International Medical and Dental Research

E-ISSN: 2395-2822 | P-ISSN: 2395-2814

Vol-8, Issue-1 | January-February 2022

DOI: $10.53339 /$ aimdr.2022.8.1.14

Page no- 98-105 | Section- Research Article (Surgical Gastroenterology)

Guidelines on Enteral Nutrition: Terminology, definitions and general topics. Clin Nutr. 2006;25(2):180-6. doi: 10.1016/j.clnu.2006.02.007.

9. Keller U. Nutritional Laboratory Markers in Malnutrition. J Clin Med. 2019;8(6):775. doi: 10.3390/jcm8060775.

10. Reber E, Gomes F, Vasiloglou MF, Schuetz P, Stanga Z. Nutritional Risk Screening and Assessment. J Clin Med. 2019;8(7):1065. doi: 10.3390/jcm8071065.

11. Klek S, Hermanowicz A, Dziwiszek G, Matysiak K, Szczepanek K, Szybinski P, et al. Home enteral nutrition reduces complications, length of stay, and health care costs: results from a multicenter study. Am J Clin Nutr. 2014;100(2):609-15. doi: 10.3945/ajen.113.082842.

12. Wang Y, Kang Y, Zhou JR. Comparison of two types of enteral nutrition in patients with intestinal fistula. Zhonghua Yi Xue Za Zhi. 2013;93(30):2364-6.

Source of Support: Nil, Conflict of Interest: None declared 